\title{
Petrological Composition of the Last Coal Seam in the Longmendong Section before the End-Permian Mass Extinction
}

\author{
Chunguang Zhang ${ }^{1,2}\left(\mathbb{D}\right.$, Jun Wang ${ }^{1,2, *}$, Mingshi Feng ${ }^{1,2}$, Zhiqiang Shi ${ }^{1,2}$, Fang Xiang ${ }^{1,2}$, Mingcai Hou ${ }^{1,2}$, \\ Shuai Yang ${ }^{1,2}$, Ben Kneller ${ }^{3}$ and Hongde Chen ${ }^{1,2}$
}

1 Institute of Sedimentary Geology, Chengdu University of Technology, Chengdu 610059, China; zcg@stu.cdut.edu.cn (C.Z.); fengmingshi09@cdut.edu.cn (M.F.); shizhiqiang@cdut.cn (Z.S.); xiangf@cdut.edu.cn (F.X.); Houmc@cdut.edu.cn (M.H.); yangshuai17@cdut.edu.cn (S.Y.); chd@cdut.edu.cn (H.C.)

2 State Key Laboratory of Oil and Gas Reservoir Geology and Exploitation, Chengdu University of Technology, Chengdu 610059, China

3 School of Geosciences, University of Aberdeen, Aberdeen AB24 3UE, UK; b.kneller@abdn.ac.uk

* Correspondence: wangjun07@cdut.edu.cn

check for

updates

Citation: Zhang, C.; Wang, J.; Feng, M.; Shi, Z.; Xiang, F.; Hou, M.; Yang, S.; Kneller, B.; Chen, H. Petrological Composition of the Last Coal Seam in the Longmendong Section before the End-Permian Mass Extinction. Minerals 2021, 11, 1230. https:// doi.org/10.3390/min11111230

Academic Editors: Thomas Gentzis, Shifeng Dai and David French

Received: 9 September 2021

Accepted: 2 November 2021

Published: 5 November 2021

Publisher's Note: MDPI stays neutral with regard to jurisdictional claims in published maps and institutional affiliations.

Copyright: (c) 2021 by the authors. Licensee MDPI, Basel, Switzerland. This article is an open access article distributed under the terms and conditions of the Creative Commons Attribution (CC BY) license (https:// creativecommons.org/licenses/by/ $4.0 /)$.

\begin{abstract}
Late Permian coal deposits are widely distributed throughout southwestern China. This paper describes the petrological composition of the last coal seam in the Longmendong section of the Emeishan area during the latest Changhsingian (Permian) and records important information regarding the evolution of the mass extinction event that occurred at the end of the Permian. The results show that the dominant coal maceral group is vitrinite, followed by liptinite and inertinite macerals, and the coal minerals include quartz, chamosite and pyrite. The pyrofusinite and carbon microparticles occurrence modes could have been formed during wildfires in the adjacent areas. The $\beta$-tridymite occurrence modes and the high proportions and occurrence modes of magmatic quartz indicate that synchronous felsic volcanic activity occurred during the peat mire accumulation period. The chamosite and quartz occurrence modes suggest that they primarily precipitated from Fe-Mg-rich siliceous solutions that was derived from the weathering of nearby Emeishan basalt. The pyritic coal balls occurrence modes in the $\mathrm{C} 1$ coal seam are likely the result of coal-forming plants and Fe-Mg-rich siliceous solutions in neutral to weak alkaline conditions during late syngenetic stages or early epigenetic stages within paleomires.
\end{abstract}

Keywords: coal; maceral composition; wildfire; volcanic activity; Emeishan basalt; latest Changhsingian

\section{Introduction}

Coal is considered to be one of the most complex geological materials and consists of a combination of organic and mineral matter [1]. The organic components in coal have high energy potential and are used to characterize the coal deposit [2-4]. Coal is well known to possess a wide variety of minerals [5-9]. Coal mineralogy is therefore a crucial aspect to understanding the inorganic processes involved in its formation [10-12]. In particular, coal minerals provide important information regarding the local geological history and depositional conditions of coal-bearing sequences [13-20], in addition to the regional tectonic and sedimentary history [21]. The mineral assemblages in coal can also be used to determine the paleoenvironmental conditions of peat accumulation and coal formation [22-28].

The Late Permian was a major coal-forming period, and Late Permian coal deposits are widely distributed throughout southwestern China, including Yunnan, Guizhou and Sichuan [21]. The Late Permian siliciclastic coal measures in eastern Yunnan, southern Sichuan and western Guizhou comprise the largest coal reserves in all of southern China, forming a transitional paralic plain and nonmarine alluvial setting [29], despite some 
preserved coal seams within marine carbonate sequences [30-33]. Previous studies focused on marine/nonmarine transitional environment areas related to coalfields including Yunnan [21,22], Guizhou [34,35], Guangxi [32,33], Chongqing [36,37] and Sichuan [38,39]. However, research on coal seams in a terrestrial mire-lacustrine-fluvial environment is very rare, despite the fact that it contains important information about the material source of Late Permian coals.

The end-Permian mass extinction event (EPE) was the most extreme biological crisis on Earth, with a substantial loss of marine and terrestrial species. The extinction occurred on a global scale and is most commonly attributed to a large release of greenhouse gases owing to volcanic activity of the Siberian Traps $[40,41]$ and/or of other areas [42,43]. The PermoTriassic boundary (PTB) in the Sydney Basin [44] has historically been placed at the top of the uppermost coal seam in the sequence (i.e., the Katoomba Coal Member in the west of the basin, Bulli Coal in the south and the Vales Point coal seam in the north). Fielding et al. [45] concluded that the top of the Bulli Coal marks the most pronounced floristic turnover and is equated with the continental EPE. Vajda et al. [43] thought the uppermost unit of the coal measures represents peat accumulation immediately preceding the EPE. In South China, the last coal seam in nonmarine transitional environments is coincident with the marine mass extinction based on stratigraphic range data and biological evidence [46]. The first report of pyritic coal balls [47] in China was from the research of the last coal seam in nonmarine transitional environments in the Wangjiazhai Formation, Shuicheng Coal Mining District, Guizhou Province. The last appearance of coal in a terrestrial environment is at the bottom boundary of the Permian-Triassic transitional Kaiyitou Formation in South China [46], which provides an important record of the evolution of the EPE. The petrological composition of the last coal seam is critical to understanding the sources of minerals in coal and the geological processes to which coal has been subjected. More importantly, the last coal seam provides basic data for the EPE in South China and thus provides some evidence for the cause of the EPE. This coal seam is thus worthy of detailed investigation.

\section{Geological Setting}

During the Permian-Triassic transition, South China was considered to be an isolated island in a tropical zone of the eastern Tethyan gape (Figure 1A) based on recent palaeogeographical reconstructions [48,49]. A large $\left(\sim 300,000 \mathrm{~km}^{2}\right)$ coal-bearing depositional system formed during the Late Permian along the eastern edge of this volcanic plateau owing to the undulating basalt mountains formed by the eruption of the Emeishan basalt in the Late Guadalupian (Middle Permian). These processes allowed terrestrial alluvial and transitional coastal deposits to accumulate along the peripheral areas [49]. The Emeishan flood basalt eruptions were extensive and led to the formation of the Kangdian Oldland [50]. The magma from the primary eruption period evolved from mafic to felsic and alkaline compositions [21], as confirmed by the widespread distribution of mafic, silicic and alkaline tonsteins in southwestern China [36,51].

The Xuanwei Formation, disconformably overlying the Emeishan Basalt Formation, formed in a terrestrial mire-lacustrine environment. It is the major coal-bearing interval and is mainly composed of grey, olive or multicolored sandstone; mudstone and some coal seams, none of which are minable [49] (Figure 1C). The Xuanwei Formation is approximately $37.8 \mathrm{~m}$ thick in the study area [46]. The base of the transitional Kaiyitou Formation is defined as the top of the final coal seam and the top of the final olive rock [46,49]. According to this definition, the Kaiyitou Formation is approximately $6.0 \mathrm{~m}$ thick in the Longmendong section and does not contain coal seams [46]. The composition of the Dongchuan Formation is uniform and consists of maroon/purple sandstone and silty breccia [46]. 


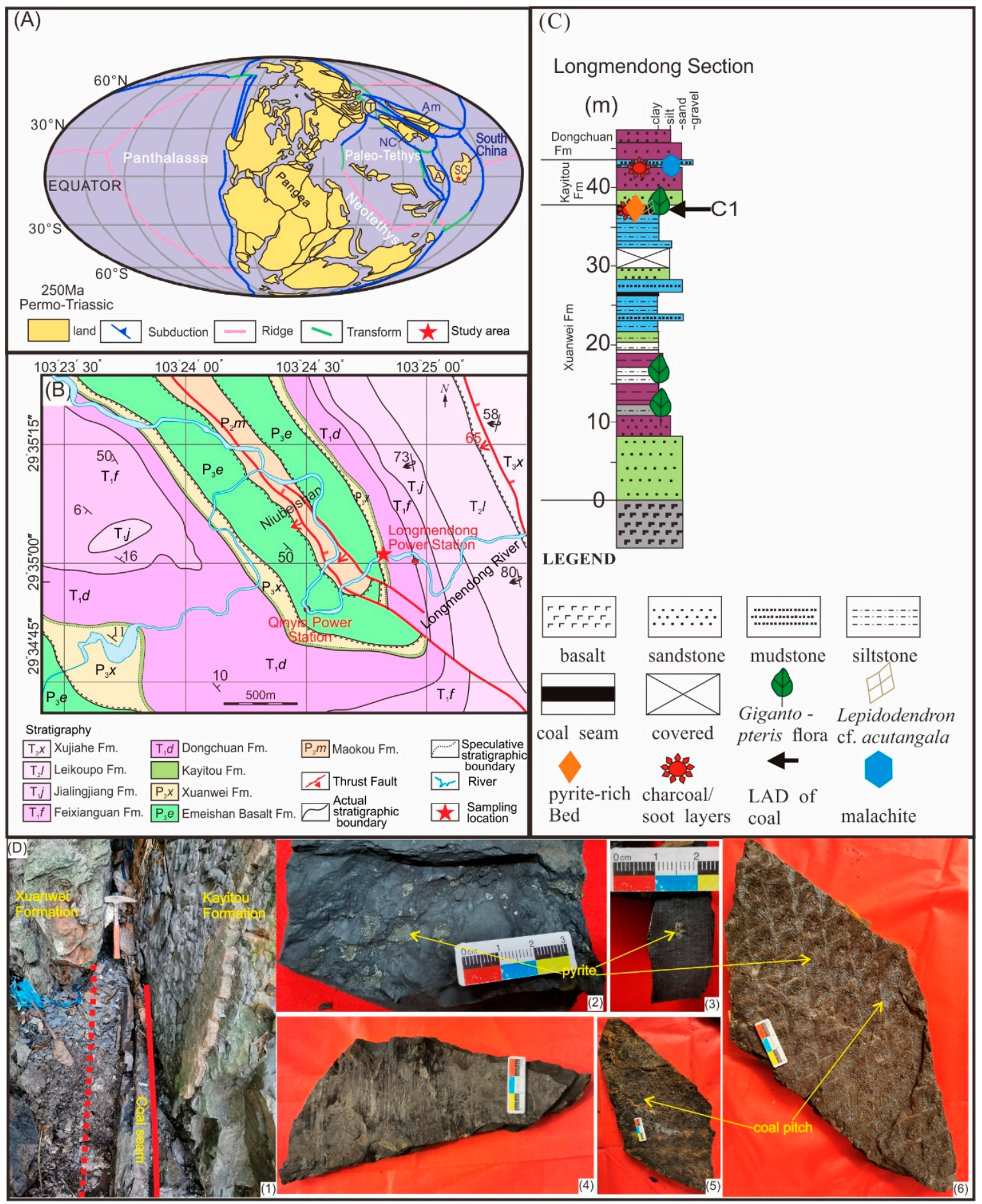

Figure 1. (A) Global paleogeographic plate reconstruction at $250 \mathrm{Ma}$ (Permo-Triassic boundary) (modified from [52]). Abbreviated continental units: A, Annamia; Am, Amuria; NC, North China; SC, South China; (B) Simplified geological map of the Longmendong area (modified from [53]); (C) Stratigraphic section and sampling location of the Longmendong section (modified from [46]). The lithology coloring approximately represents that of the rocks according to the Munsell color system; (D) Outcrop and macroscopic photographs of the last coal seam in the Longmendong section, the detailed description of the figures can be seen in Part 3. 


\section{Sampling and Analytical Methods}

The area investigated in this study is located along the northeastern margin of the Kangdian Upland. The studied samples were collected from the Longmendong section $\left(29^{\circ} 34^{\prime} 43.99^{\prime \prime} \mathrm{N}, 103^{\circ} 24^{\prime} 59.50^{\prime \prime} \mathrm{E}\right)$, which is located in Huangwan Town, Emeishan City, Sichuan Province. The Permian-Triassic sedimentary sequences (Figure 1B) in the Longmendong section include in ascending order: the Emeishan Basalt Formation, Xuanwei Formation, Kaiyitou Formation and Dongchuan Formation [46]. The last coal seam (C1) of the Xuanwei Formation has a thickness of $0.4 \mathrm{~m}$, which is poorly preserved (Figure 1(D1)). The sample we analyzed is at the top of the coal seam, and it is grey black, the weathering surface is light yellow, and endogenous cracks are not developed (Figure 1(D1,D2)). The structure is linear and striped due to variations in coal composition (Figure 1(D3)). Pyrite is distributed in strips or lenses along the coal seam (Figure 1(D2,D3)), accounting for a minor proportion. Fossils with plant wood tissue structures (Figure 1(D6)) can be seen on the surface of the coal, identified as Lepidodendron cf. acutangala, which are oriented parallel to the layer. The surface is characterized by being covered with spirally-arranged leaf seats from rhombus to rhombus; there are zigzag and protruding separation bands between the intervals of the leaf seats, which cause the trunk surface to have a notably tortuous appearance (Figure 1(D6)). Plant fossils are replaced by coal tar pitch and pyrite, and the preservation is relatively complete. The coal tar pitch (Figure 1(D3,D5,D6)) is similar to coal in appearance, being granular, shiny, black, brittle and being without layering and with obvious scratches (Figure 1(D4)).

The samples were carefully collected to minimize contamination. Random reflectance of vitrinite was measured by a Leica DM4P microscope at the Sinopec Zhongyuan Oilfield based on SY/T 5124-2012. Microscopic identification of the macerals and subdivision into maceral types were performed under both transmitted light and fluorescence excitation using a DM6M microscope at the Sinopec Zhongyuan Oilfield, based on SY/T 5125-2014. The XRD analysis was performed on a powder diffractometer with Ni-filtered $\mathrm{Cu}-\mathrm{K} \alpha$ radiation and a scintillation detector. The mineralogy was determined by optical microscopy, coal petrography microscopy and scanning electron microscopy (SEM). A FEI Quanta 250 FEG field emission environment scanning electron microscope (SEM) (PO, USA) fitted with OXFORD INCAx-max20 energy-dispersive X-ray spectrometers (EDS) (High Wycombe, Buckinghamshire, UK) was used to investigate the surface characteristics and associated coal chemistry. Due to the complex composition, variable structure and strong heterogeneity of the coal seam, we selected multiple samples for SEM analysis, including naturally exposed and ion-polished samples. All samples were first coated with gold using an Emitech K550X sputter coater (UK) to increase electrical conductivity. The SEM working distance was set to $10 \mathrm{~mm}$, and the beam acceleration voltage was $20.0 \mathrm{kV}$.

\section{Results}

\subsection{Maceral Compositions}

The macerals analyses show that the $\mathrm{C} 1$ coal seam is composed of three maceral groups, consisting of vitrinite $(74.2 \mathrm{vol} \%)$, liptinite (19.6 vol\%) and inertinite (6.2 vol\%) (Figure 2A,B). Microphotographs of the polished blocks from the coal petrography microscope show that vitrinite is mainly composed of collotelinite (Figure 2E) and collodetrinite (Figure 2D), and telinite is rare (Figure 2C). Collotelinite (CT) has uniform brightness and is distributed in strips (Figure 2E). There are often endogenous fissures in collotelinite, which have been filled by minerals (Figure 2F). Collodetrinite (CD) often occurs as a matrix of cementation minerals distributed in strips and bifurcated strips, which form a clear contrast with the cemented components (Figure 2D,G). Typical liptinite groups are not seen in the polished blocks from a coal petrography microscope. Inertinite macerals are dominated by fusinite and semifusinite. Degradofusinite appears bright white under reflected light, and the gradual transition from vitrinite to inertinite was observed in the same plant fragment (Figure 2F). Pyrofusinite appears bright yellowish white under reflected light, which was deformed by compression and mineralized by clay minerals (Figure $2 \mathrm{H}-\mathrm{J}$ ). Semifusinite 
appears grey to yellowish white under reflected light, and plant tissues are well-preserved. In addition, a few carbon microparticles can be observed (Figure 2L). The $\mathrm{C} 1$ coal seam is anthracite coal $(\mathrm{Rr}=2.7 \%)$ through the measurement of 42 points, the maximum reflectivity is 3.0 , and the standard deviation is 0.1 .
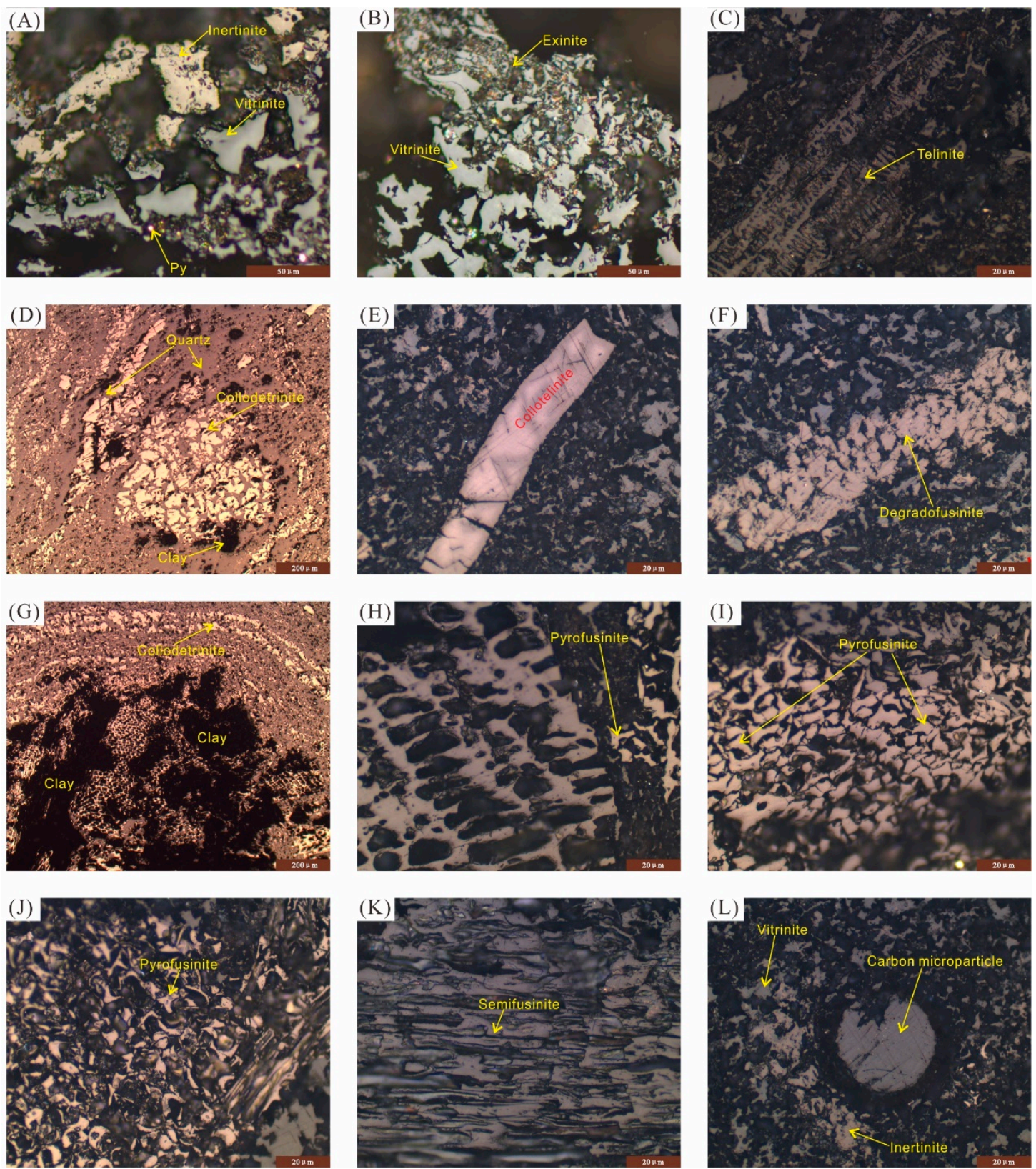

Figure 2. Vitrinite, liptinite and inertinite macerals in the C1 coal. (A) Vitrinite and inertinite; (B) Vitrinite and liptinite; (C) Lepidophytotelinite showing secondary xylem and scalariform pits; (D) Oxidized collodetrinite with dessication cracks; (E) Oxidized collotelinite with dessication cracks; (F) Degradofusinite showing the transition from vitrinite to inertinite; (G) Inertinite showing well-preserved cell structure; $(\mathbf{H})$ Magnification of $(\mathbf{G})$, lepidophytofusinite (peridem) and pyrofusinite; (I) Magnification of (G), pyrofusinite showing 'bogen' structure; (J) Magnification of (G), pyrofusinite showing 'bogen' structure; (K) Semifusinite with well-preserved cell structure; (L) Ellipsoidal carbon microparticle displaying homogeneneous structure, showing the transition from vitrinite to inertinite. All photomicrographs were taken under reflected light, (A,B) maceral plate; (C-L) polished blocks; (A,B,D,G) dry objective; $(\mathbf{C}, \mathbf{E}, \mathbf{F}, \mathbf{H}-\mathbf{L})$ oil immersion. 


\subsection{Mineral Occurrence Modes}

The XRD analysis (Figure 3) shows that quartz (86.1\%) is the dominant mineral in the $\mathrm{C} 1$ coal seam, followed by clay minerals (mainly chlorite and a trace amount of kaolinite) and minor pyrite minerals $(1.4 \%)$. The chlorite in the $\mathrm{C} 1$ coal seam is identified as chamosite rather than clinochlore due to the reduced intensity of the odd-order peaks. The SEM-EDS analysis and optical microscopic observations are in agreement with the XRD results.

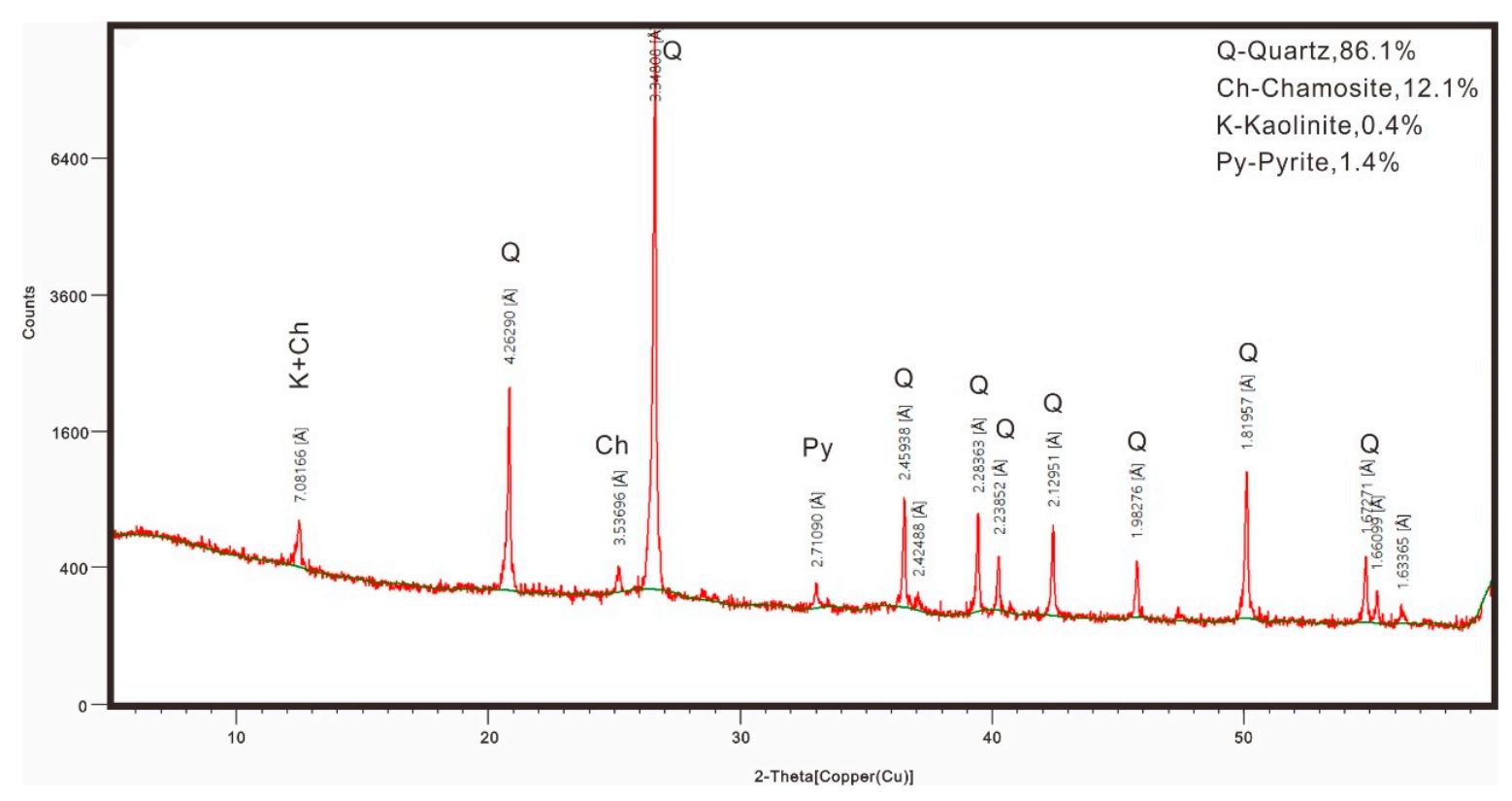

Figure 3. X-ray power diffraction patterns of $\mathrm{C} 1$ coal.

\subsubsection{Quartz}

The following four quartz modes occur in the $\mathrm{C} 1$ coal seam: (1) Fine-grained quartz crystals (Figure 4A,B) appear as angular fragments or corroded particles restricted to organic matter, which account for a substantial component of the total material. A minor amount of larger detrital quartz grains occur in subangular or subrounded forms within the organic matter and long axes approximately parallel to the bedding direction (Figure 4C). (2) Quartz associated with chamosite occurs within the cell cavities and cleat/fracture infillings (Figure 4E,F). (3) High-temperature quartz was found in the C1 coal (Figure 4G-K), and its crystals are hexagonal plates and arranged in clusters and shingles. It is defined as $\beta$-tridymite according to its crystalline characteristics. (4) There is a minor amount of authigenic quartz (Figure 4D,L).

\subsubsection{Chamosite}

The XRD and SEM-EDS analyses indicate that chamosite is the dominant clay mineral in the $\mathrm{C} 1$ coal seam (Figure 5E). The following five chamosite modes occur in the $\mathrm{C} 1$ coal seam: (1) Chamosite closely associated with the quartz component occurs mainly as cleat/fracture infillings, accounting for a substantial proportion (Figures $4 \mathrm{D}, \mathrm{F}$ and $5 \mathrm{I}, \mathrm{J}, \mathrm{L}$ ), and in some cases distributed solely in organic matter (Figure 5G). (2) Chamosite occurs as cleat/fracture infillings within pyritic coal balls (Figure 5D,E). (3) Chamosite occurs as a fibrous aggregate that envelops organic matter (Figure 5A,G,H). (4) Chamosite occurs as cell infillings, which account for a minor proportion (Figure 5F). (5) The chloritic matrix is associated with volcanic matter, accounting for a lower yet significant proportion of the mineral material (Figure 5C). 

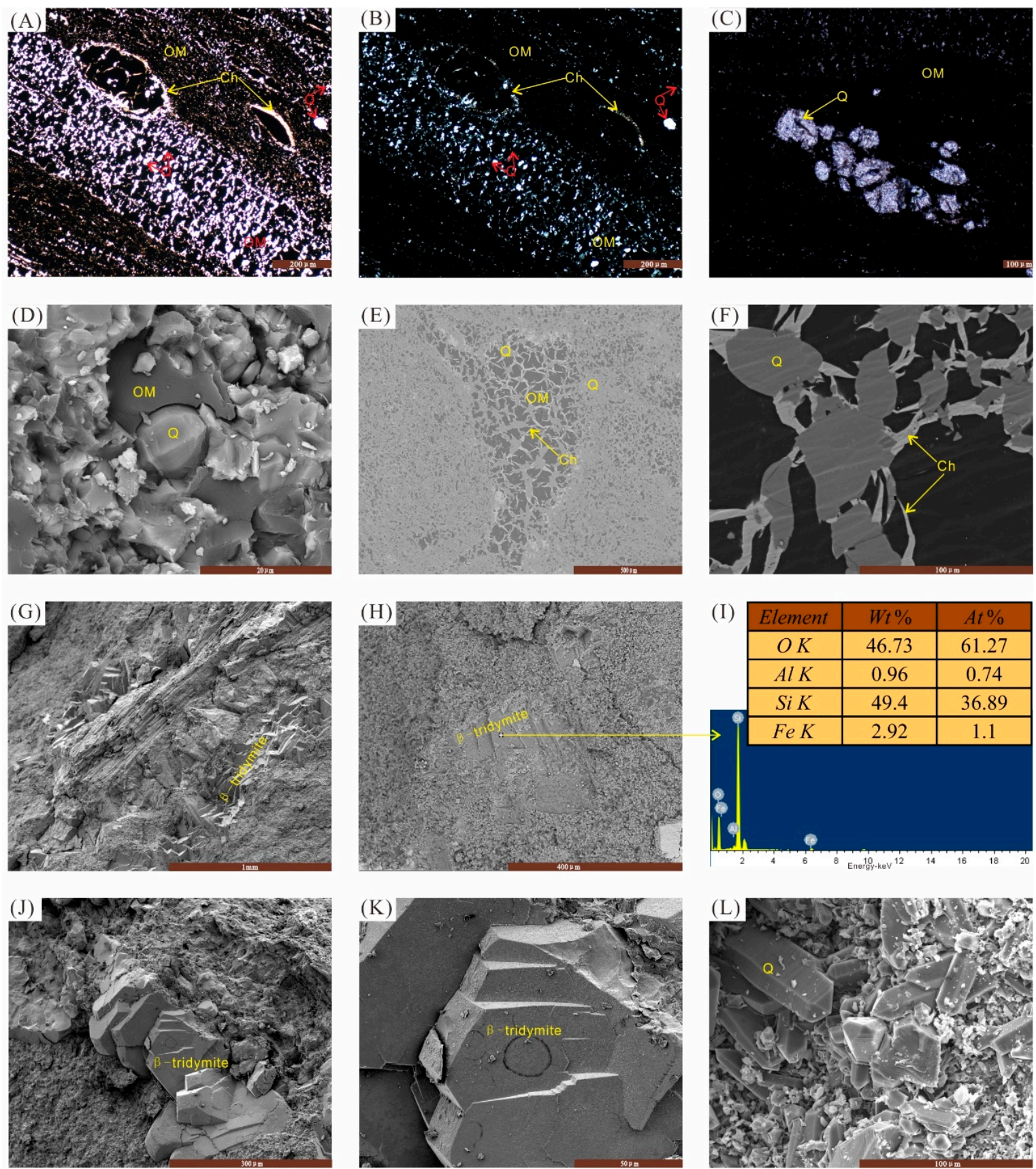

Figure 4. Quartz occurrence modes in coal. (A) Fine-grained quartz grains appear as angular fragments or corroded particles restricted to organic matter in plane-polarized light (PPL); (B) Photomicrographs of (A) under polarized light (XPL); (C) Discrete larger well-developed quartz in organic matter in PPL; (D) Discrete authigenic quartz particle in organic matter SEM BSED; (E) Quartz as cleat/fracture infillings closely associated with chamosite SEM BSED; (F) Quartz as cleat/fracture infillings closely associated with chamosite SEM BSED; (G) $\beta$-tridymite arranged in clusters and shingles SEM BSED; (H) $\beta$-tridymite arranged in clusters and shingles SEM secondary electron images (ETD); (I) EDS data for $\beta$-tridymite; (J) $\beta$-tridymite occurring as hexagonal plates and arranged in clusters and shingles SEM ETD; (K) Magnification of (J) SEM ETD; (L) Authigenic quartz particles SEM ETD. Q, quartz; Ch, chamosite; OM, organic matter. (D,G,H,J-L) naturally exposed surface; $(\mathbf{E}, \mathbf{F})$ ion-polished surface. 

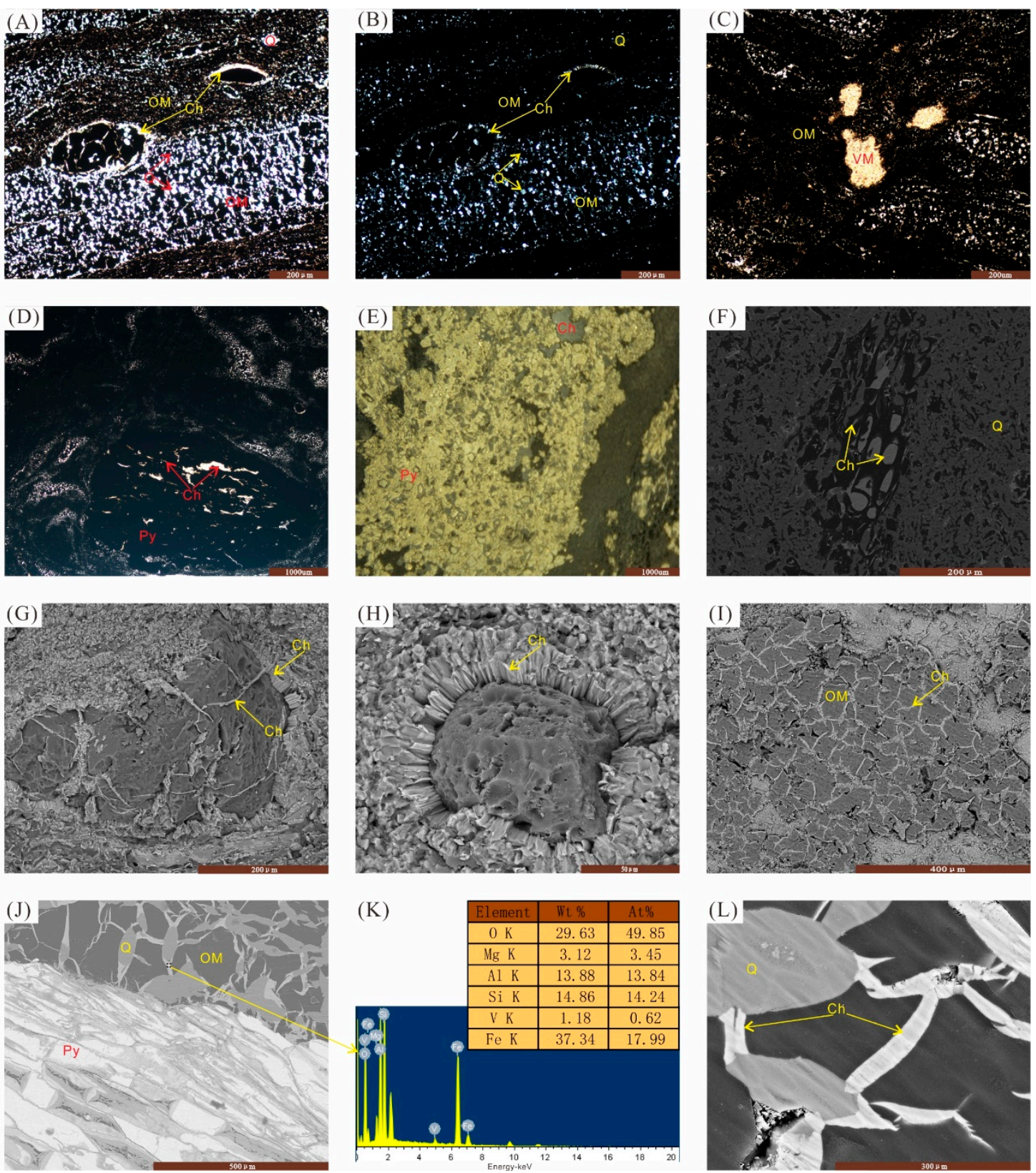

Figure 5. Chamosite occurrence modes in coal. (A) Fibrous aggregate that envelops organic matter and occurs as cleat/fracture infillings in PPL; (B) Photomicrographs of (A) under XPL; (C) Chloritic matrix associated with volcanic matter in PPL; (D) Chamosite as cleat/fracture infillings within pyritic coal balls in PPL; (E) Photomicrographs of (D), reflected light in air; (F) Chamosite as cell infillings SEM BSED; (G) Fibrous aggregate that envelops organic matter and occurs as cleat/fracture infillings SEM BSED; (H) Fibrous aggregate that envelops carbon microparticle SEM BSED; (I) Chamosite as cleat/fracture infillings closely associated with quartz component SEM BSED; (J) Chamosite as cleat/fracture infillings closely associated with quartz component SEM BSED; (K) EDS data for chamosite; (L) Chamosite as cleat/fracture infillings closely associated with quartz component SEM BSED. Py, pyrite; Q, quartz; Ch, chamosite; OM, organic matter; VM, volcanic matters. (G-I) the naturally exposed surface; $(\mathbf{F}, \mathbf{J}, \mathbf{L})$ ion-polished surface.

\subsubsection{Pyrite}

Pyrite is the only sulfide mineral detected by XRD in the C1 coal seam. Pyrite can be found to replace some of the maceral components owing to a large amount of pyrite on the surface of Lepidodendron (Figures 1(D6) and 6C,D). The SEM images show that the pyrite form on the bedding surface has a good crystalline structure, which indicates that it might have 
been formed during the epigenetic stage. Pyrite nodules in the $\mathrm{C} 1$ coal seam can occur as individual euhedral grains (Figures $1(\mathrm{D} 3$ ) and $6 \mathrm{~A}, \mathrm{~B}, \mathrm{E}$ ) or in a chain arrangement (Figure 6G). Notably, pyrite also occurs as coal balls, accounting for a large proportion in pyrite nodules.
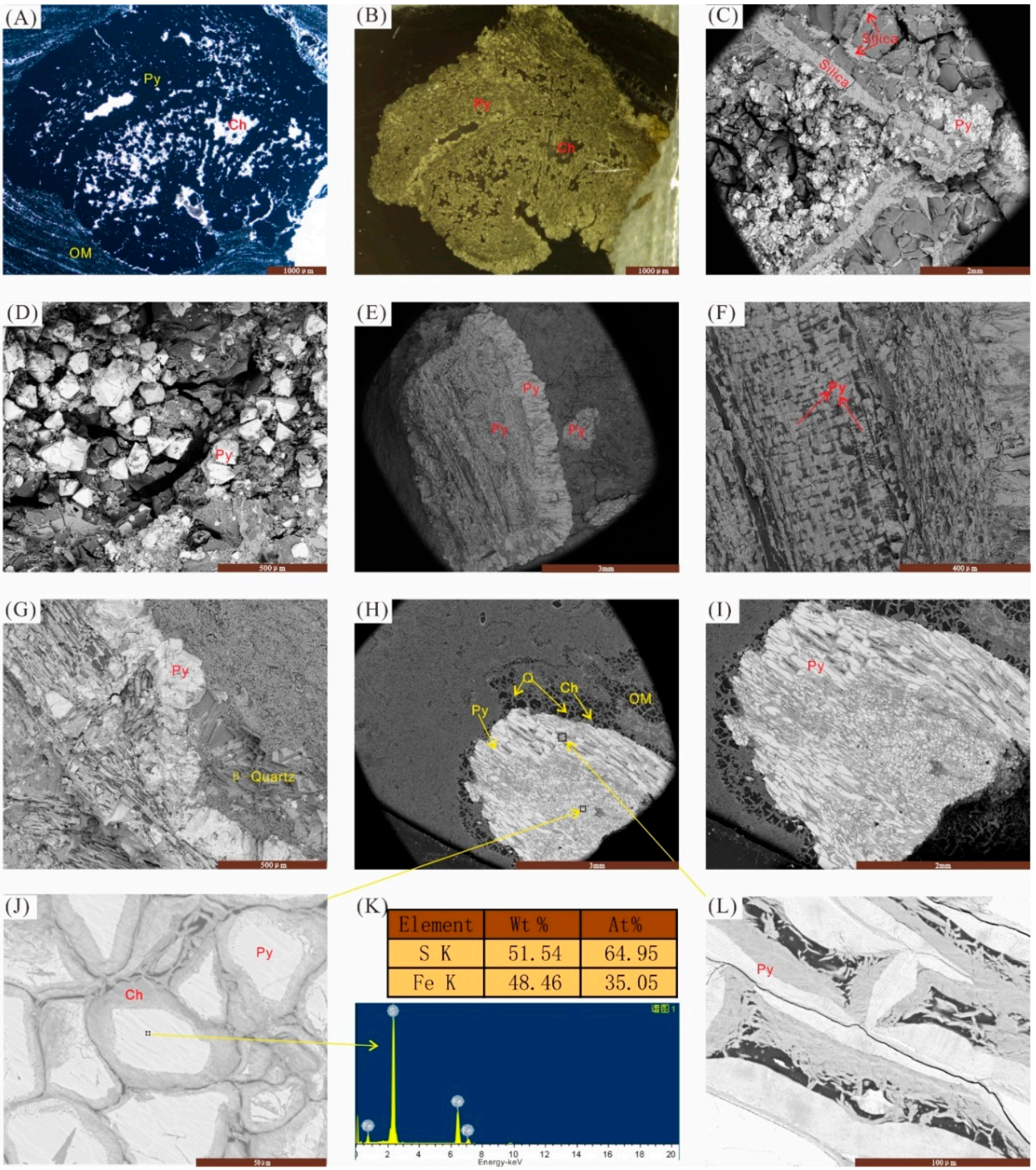

Figure 6. Pyrite occurrence modes in coal. (A) Pyrite occurring as isolated euhedral particles in plane-polarized light (PPL); (B) Photomicrographs of (A), reflected light in air; (C,D) Pyrite on the surface of Lepidodendron. SEM back-scattering images (BSED); (E) Pyritic coal balls SEM BSED; (F) Magnification of (E), vegetative organs and reproductive organs with well-preserved plant cell tissue SEM BSED; (G) Pyrite aggregates in bands that are parallel to the stratification direction SEM BSED; (H) Pyritic coal balls as isolated anhedral bodies in collodetrinite SEM BSED; (I) Magnification of $(\mathbf{H})$, pyritized tissues with different form SEM BSED; (J) Magnification of (H), pyrite enclosed by the Fe-Mg-rich siliceous material SEM BSED; (K) EDS data for pyrite; (L) Magnification of (H), the remnants of organic matter SEM BSED. Py, pyrite; Q, quartz; $\mathrm{Ch}$, chamosite; $\mathrm{OM}$, organic matter. $(\mathbf{C}-\mathbf{G})$ naturally exposed surface; $(\mathbf{H}-\mathbf{J}, \mathbf{L})$ ion-polished surface.

The SEM images show that vegetative organs and reproductive organs of plant cell tissues are well preserved inside the pyritic coal balls (Figure 6E,F), indicating that pyritic coal balls originated late in the peat stage, but before the peat was strongly compacted [54]. 
The SEM images (Figure 6H-J,L) of ion-polished surfaces show that organic matter or plant tissues are replaced by pyrite. Pyrite within coal balls is enclosed by the Fe-Mgrich siliceous material (Figure 6J), and minor remnants of organic matter can be seen (Figure 6L). These could have been formed either during late syngenetic stages or early epigenetic stages.

\section{Discussion}

\subsection{Evidence of Wildfires}

A fire requires an ignition source, oxygen supply and fuel to burn [55]. Natural fires can be caused by spontaneous ignition, lightning, volcanic eruption, friction [55] and, on rare occasions, by meteorite impacts [56]. Late Permian rocks contain numerous records of volcanic episodes [42], which could have provided ignition conditions for wildfires. Atmospheric composition models of the latest Permian indicate an oxygen level of 22\% [57], which is very similar to that of today. This is particularly important because atmospheric oxygen levels are related to the frequency and intensity of wildfires [58], and higher oxygen levels are associated with more intense and more frequent fires. The Xuanwei Formation floras in South China are dominated by the species of both Gigantopteris and Gigantonoclea, other kinds such as Annularia shirakii and Lepidodendron acutangulum are also commonly present [25]. The last coal seam from the Longmendong section is rich in lycopsid plants, which could provide fuel for wildfires.

Wildfire activity can preserve intricate organic structures such as charcoal [55,59-61], whereas charring can cause the organic tissues to change chemically and structurally [62]. Inertinite macerals are always replaced by pyrite in the $\mathrm{C} 1$ coal seam (Figure 7A-C), being embedded within collodetrinite. In some cases, pyrofusinite and semifusinite macerals are associated with clay minerals and embedded within collodetrinite (Figures 2G-K and 7D-F). This points to an allochthonous origin of inertodetrinite transported by wind or water into the palaeomire [3]. The SEM images provide anatomical evidence of charring, including the homogenization of the cell walls and three-dimensional cellular preservation in the $\mathrm{C} 1$ coal (Figure 7G,H). These characteristics provide anatomical criteria for recognizing the formation of charcoal from the burning of living trees [63]. To some extent, pyrofusinite can be used as direct geological evidence of a wildfire during peat mire accumulation. Some carbon microparticles can also be seen in the coal seam (Figures 2L and 7I-L), which occur as the chaotic accumulation associated with chamosite (Figure 7I). The carbon microparticles occurrence modes could be formed during wildfires in the adjacent areas. Although there is no standard definition, carbon microparticles are generally considered to be a type of carbon-containing particulate matter produced by the incomplete combustion of biological matter or fossil fuels.

\subsection{Emeishan Basalt as a Primary Source Region}

A major source of the inorganic constituents of coal is detrital material [64], which supports the conclusion that the Late Permian coal seam had a terrestrial source area in the Longmendong section. The Kangdian Upland is mostly composed of Emeishan basalts and provided terrigenous materials for the majority of the coal-bearing areas of the Late Permian age in southwestern China [7,29,65].

Kaolinite is the most common clay mineral in these coals and tonsteins in the Late Permian deposits throughout southwestern China [36,66,67]. However, chamosite is the only clay mineral that can be observed in the $\mathrm{C} 1$ coal seam. Dai and Chou [22] reported that kaolinite was replaced by chamosite in the cell cavities of a semianthracite specimen from the Zhaotong Coalfield (southwestern China). They suggested that the chamosite formed during early diagenesis owing to a reaction between kaolinite and Fe-Mg-rich fluids. Chamosite was also suggested to have formed in the thermally metamorphosed Bukit Asam coal from reactions between kaolinite and Fe and Mg ions, which were likely derived from the organic matter of higher-rank coals [68]. Chamosite occurs mainly as cleat/fracture infillings, which clearly show that their formation was epigenetic. Chamosite 
also occurs as a fibrous aggregate that envelops organic matter (Figure $3 \mathrm{G}, \mathrm{H}$ ), which may be evidence of the circulation of Fe-Mg-rich solutions. The Longmendong section is the closest terrestrial section to the Kangdian Upland in previous studies. The formation of the chamosite in the $\mathrm{C} 1$ coal seam may thus be by direct precipitation from Fe-Mg-rich hydrothermal fluids.
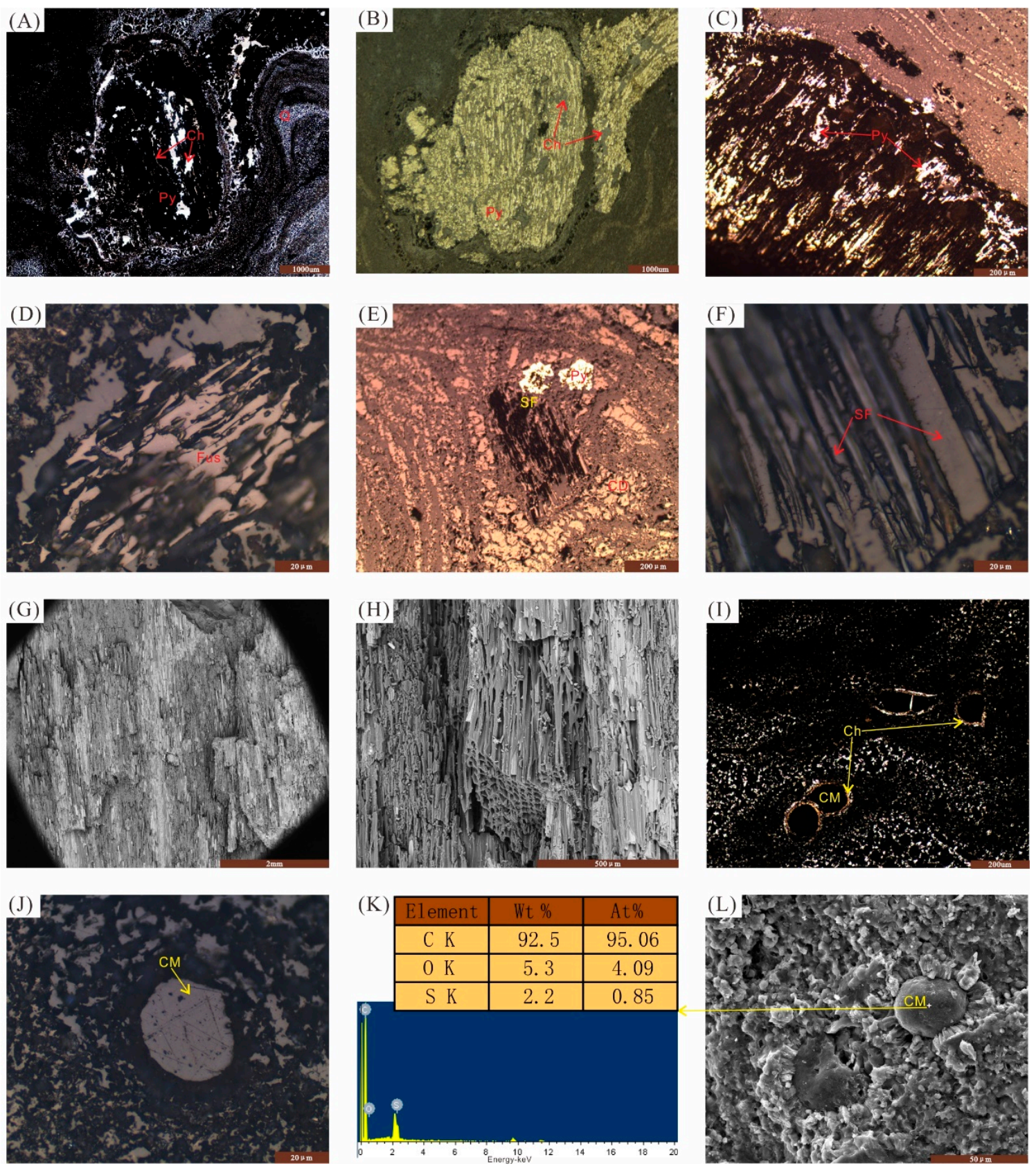

Figure 7. Charcoal and carbon microparticles in coal. (A) Pyritized fusinite embedded within collodetrinite in PPL; (B) Photomicrographs of (A), reflected light in air; (C) Inertinite (linear) under reflected light (dry objective); (D) Pyrofusinite with well-preserved cell structure under reflected light (oil immersion); (E) Inertinite associated with clay minerals under reflected light (dry objective); (F) Magnification of (E), semifusinite with well-preserved cell structure under reflected light (oil immersion); (G) Micrograph of charcoal SEM BSED; (H) Magnification of (G), transverse view of a fragment of charcoal, showing homogenized cell walls and three-dimensional cellular preservation SEM BSED; (I) Carbon microparticles in PPL; (J) Carbon microparticle under reflected light (oil immersion); (K) EDS data for carbon microparticle; (L) Carbon microparticle SEM ETD. Py, pyrite; Q, quartz; Ch, chamosite; Fus, fusinite; SF, semifusinite; CM, carbon microparticle. 


\subsection{Input of Felsic Volcanogenic Matter}

Previous studies have reported that alkali tonsteins developed during the early part of the Late Permian in southwestern China [51,69]. However, the geochemistry of several coal tonsteins of the Late Permian age worldwide indicates that they originated from volcanic ash fallout of silicic to intermediate composition [70-76]. The systematic investigation of volcanic tuff/ash is focused on the marine environment, but their origin is still uncertain $[42,77,78]$. The last appearance of coal, as a thin seam, is taken as the beginning of the terrestrial end-Permian mass extinction event in South China, basically consistent with Bed 25 at the marine Meishan section [49]. Radiometric dating of the ash bed (Bed 68) at the Chahe section is $252.30 \pm 0.07 \mathrm{Ma}$ [46]. It is noteworthy that there are two tonstein layers in the $\mathrm{C} 1$ coal seam in the Xuanwei area, eastern Yunnan Provinces [75,76], which could provide a unique perspective on the end-Permian mass extinction event.

Although no tonstein layers were identified in the $\mathrm{C} 1$ coal seam in our study area, the high proportions and occurrence modes of quartz (angular quartz and corroded quartz arranged in a random direction) in the $\mathrm{C} 1$ coal seam indicate a volcanic origin during the peat accumulation phase. Previous studies have shown that $\beta$-quartz crystals generally exhibit only a bipyramidal habit [79] without additionally developed prism faces [11]. High-temperature quartz is common in the Late Permian coals of southern China and exhibits well-developed crystal forms [21,65]. The $\beta$-quartz is considered to have originated from the in situ alteration of syngenetic-acidic or acidic-intermediate volcanic ashes in the coal seams $[11,79]$. The $\beta$-tridymite occurrence modes in the $C 1$ coal seam thus suggest that they originated from a felsic volcanic source. Hexagonal $\beta$-tridymite is formed only when the crystallization temperature is higher than $1117^{\circ} \mathrm{C}$, and because there is no evidence of such high-temperature fluids, its formation can likely be attributed to magma chamber growth rather than dissolution following its precipitation in the peat mire. The common presence of $\beta$-quartz polymorphs in the coals of southern China indicates that frequent felsic volcanic eruptions likely occurred during the Late Permian. This further suggests that felsic ashes from within the Late Permian coals likely resulted from a range of felsic magma chambers or different stages of evolution within the same magma chamber.

\subsection{Formation of Pyritic Coal Balls and Its Geological Significance}

Pyrite is common in coal and coal-bearing strata influenced by marine activity [11,54], whereas pyrite deposited in coals and/or host rocks under terrestrial environment conditions is typically considered to have formed from epithermal solutions [54,80-84]. Previous studies have shown that hydrothermal fluids tend to dominate the local enrichment of certain minerals and trace elements in the Late Permian coals of southwestern China that were deposited in terrestrial conditions [85-90]. While the modes of occurrence of pyritic coal balls in the $\mathrm{C} 1$ coal seam suggest that they could have been authigenically precipitated within palaeomires, without any framboidal pyrite grains, they can be seen to imply neutral to weak alkaline conditions in the paleomires [91]. A sulfur source is inherent in coal-forming plants [54]. The source region of the mire's sediment was basaltic rocks, which provided an abundant supply of Fe to the basinal fluid. The pyrite coal balls occurrence modes in the $\mathrm{C} 1$ coal seam is thus likely the result of coal-forming plants and Fe-Mg-rich siliceous solutions in neutral to weak alkaline conditions during late syngenetic stages or early epigenetic stages within paleomires. Since the formation of pyrite coal balls requires specific sedimentary conditions, it thus can provide a basis for the comparison of palaeomires developed within marine-terrestrial transitional conditions. Besides, further research on the pyritic coal balls can play an important role in studying the flora and the paleontological evolution at the end of the Paleozoic.

\section{Conclusions}

The $\mathrm{C} 1$ coal seam is anthracite, and the dominant maceral group in the coal seam is vitrinite, which is mainly composed of collotelinite and collodetrinite, followed by liptinite and inertinite macerals. The minerals in the $\mathrm{C} 1$ coal seam are mainly dominated by quartz; 
chamosite is the only clay mineral that can be observed, and pyrite is the only sulfide mineral. The characteristic mineral assemblage in the last coal seam of the Longmendong section records important information regarding the evolution of the mass extinction event that occurred at the end of the Permian. The pyrofusinite and carbon microparticles occurrence modes could have been formed during wildfires in the adjacent areas. The high proportions and occurrence modes of magmatic quartz combined with the presence of $\beta$-tridymite indicate that felsic volcanic activity occurred during the accumulation of the peat mire. This appears to be the first report of $\beta$-tridymite in coals. The chamosite and detrital quartz occurrence modes imply that they mainly precipitated from Fe-Mg-rich siliceous solutions owing to the weathering of Emeishan basalt. The pyrite coal balls occurrence modes in the $\mathrm{C} 1$ coal seam are likely the result of coal-forming plants and Fe-rich siliceous solutions in neutral to weak alkaline conditions during late syngenetic stages or early epigenetic stages within paleomires. This appears to be the first report of pyritic coal balls in terrestrial coal seams in South China. Since the formation of pyritic coal balls requires specific sedimentary conditions, it thus can provide a basis for the comparison of nonmarine transitional and terrestrial coal seams.

Author Contributions: Conceptualization, H.C. and C.Z.; methodology, M.F.; investigation, Z.S., F.X., S.Y. and H.C.; resources, J.W.; data curation, C.Z.; writing-original draft preparation, C.Z.; writing-review and editing, J.W. and B.K.; supervision, M.H.; funding acquisition, J.W. All authors have read and agreed to the published version of the manuscript.

Funding: This research was funded by the National Natural Science Foundation of China (grant No: 41702111) and the Everest Scientific Research Program of Chengdu University of Technology (2021ZF11402).

Acknowledgments: The authors are grateful to the two anonymous reviewers and editor for handling our manuscript and providing us with careful and constructive comments on the manuscript.

Conflicts of Interest: The authors declare no conflict of interest.

\section{References}

1. Dai, S.; Hower, J.C.; Finkelman, R.B.; Graham, I.T.; French, D.; Ward, C.R.; Eskenazy, G.; Wei, Q.; Zhao, L. Organic associations of non-mineral elements in coal: A review. Int. J. Coal Geol. 2020, 218, 103347. [CrossRef]

2. Taylor, E.L.; Taylor, T.N.; Collinson, J.W. Depositional setting and paleobotany of Permian and Triassic permineralized peat from the central Transantarctic Mountains, Antarctica. Int. J. Coal Geol. 1989, 12, 657-679. [CrossRef]

3. O'Keefe, J.M.K.; Bechtel, A.; Christanis, K.; Dai, S.; DiMichele, W.A.; Eble, C.F.; Esterle, J.S.; Mastalerz, M.; Raymond, A.L.; Valentim, B.V.; et al. On the fundamental difference between coal rank and coal type. Int. J. Coal Geol. 2013, 118, 58-87. [CrossRef]

4. Thomas, L. Coal Geology, 3rd ed.; Radcliffe House: Abergavenny, UK, 2020; pp. 113-115.

5. Finkelman, R.B. Modes of occurrence of trace elements in coal. US Geol. Surv. Open File Reps. 1981, 301, 81-99.

6. Dai, S.; Jiang, Y.; Ward, C.R.; Gu, L.; Seredin, V.V.; Liu, H.; Zhou, D.; Wang, X.; Sun, Y.; Zou, J. Mineralogical and geochemical compositions of the coal in the Guanbanwusu Mine, Inner Mongolia, China: Further evidence for the existence of an $\mathrm{Al}$ (Ga and REE) ore deposit in the Jungar Coalfield. Int. J. Coal Geol. 2012, 98, 10-40. [CrossRef]

7. Dai, S.; Zhang, W.; Ward, C.R.; Seredin, V.V.; Hower, J.C.; Li, X.; Song, W.; Wang, X.; Kang, H.; Zheng, L. Mineralogical and geochemical anomalies of late Permian coals from the Fusui Coalfield, Guangxi Province, southern China: Influences of terrigenous materials and hydrothermal fluids. Int. J. Coal Geol. 2013, 105, 60-84. [CrossRef]

8. Ward, C.R. Analysis, origin and significance of mineral matter in coal: An updated review. Int. J. Coal Geol. 2016, 165, 1-27. [CrossRef]

9. Finkelman, R.B.; Dai, S.; French, D. The importance of minerals in coal as the hosts of chemical elements: A review. Int. J. Coal Geol. 2019, 212, 103251. [CrossRef]

10. Finkelman, R.B. Modes of occurrence of potentially hazardous elements in coal: Levels of confidence. Fuel Process. Technol. 1994, 39, 21-34. [CrossRef]

11. Ward, C.R. Analysis and significance of mineral matter in coal seams. Int. J. Coal Geol. 2002, 50, 135-168. [CrossRef]

12. Ward, C.; French, D. Determination of glass content and estimation of glass composition in fly ash using quantitative X-ray diffractometry. Fuel 2006, 85, 2268-2277. [CrossRef]

13. Ren, D. Mineral matters in coal. In Coal Petrology of China, 1st ed.; Han, D., Ed.; Publishing House of China University of Mining and Technology: Xuzhou, China, 1996; pp. 67-77. (In Chinese with English abstract)

14. Fowler, P.; Gayer, R.A. The association between tectonic deformation, inorganic composition and coal rank in the bituminous coals from the South Wales coalfield, United Kingdom. Int. J. Coal Geol. 1999, 42, 1-31. [CrossRef] 
15. Hower, J.C.; Gayer, R.A. Mechanisms of coal metamorphism: Case studies from Paleozoic coalfields. Int. J. Coal Geol. 2002, 50, 215-245. [CrossRef]

16. Karayiğit, A.İ.; Mastalerz, M.; Oskay, R.G.; Gayer, R.A. Coal petrography, mineralogy, elemental compositions and palaeoenvironmental interpretation of Late Carboniferous coal seams in three wells from the Kozlu coalfield (Zonguldak Basin, NW Turkey). Int. J. Coal Geol. 2018, 187, 54-70. [CrossRef]

17. Liu, H.; Jiang, B. Geochemical Alteration and Mineralogy of Coals under the Influence of Fault Motion: A Case Study of Qi'nan Colliery, China. Minerals 2019, 9, 389. [CrossRef]

18. Yang, Z.; Qin, Y.; Wu, C.; Qin, Z.; Li, G.; Li, C. Geochemical response of produced water in the CBM well group with multiple coal seams and its geological significance-A case study of the Songhe well group in Western Guizhou. Int. J. Coal Geol. 2019, 207, 39-51.

19. Hower, J.C.; Rimmer, S.M.; Mastalerz, M.; Wagner, N.J. Migmatite-like textures in anthracite: Further evidence for low-grade metamorphic melting and resolidification in high-rank coals. Geosci. Front. 2021, 12, 101122. [CrossRef]

20. Hower, J.C.; O’Keefe, J.M.K.; Valentim, B.; Guedes, A. Contrasts in maceral textures in progressive metamorphism versus near-surface hydrothermal metamorphism. Int. J. Coal Geol. 2021, 246, 103840. [CrossRef]

21. Wang, X.; Dai, S.; Chou, C.-L.; Zhang, M.; Wang, J.; Song, X.; Wang, W.; Jiang, Y.; Zhou, Y.; Ren, D. Mineralogy and geochemistry of Late Permian coals from the Taoshuping Mine, Yunnan Province, China: Evidences for the sources of minerals. Int. J. Coal Geol. 2012, 96-97, 49-59. [CrossRef]

22. Dai, S.; Chou, C.L. Occurrence and origin of minerals in a chamosite-bearing coal of Late Permian age, Zhaotong, Yunnan, China. Am. Mineral. 2007, 92, 1253-1261. [CrossRef]

23. Silva, M.B.; Kalkreuth, W.; Holz, M. Coal petrology of coal seams from the Leão-Butiá Coalfield, Lower Permian of the Paraná Basin, Brazil-Implications for coal facies interpretations. Int. J. Coal Geol. 2008, 73, 331-358. [CrossRef]

24. Holdgate, G.R.; Wallace, M.W.; Sluiter, I.R.K.; Marcuccio, D.; Fromhold, T.A.; Wagstaff, B.E. Was the Oligocene-Miocene a time of fire and rain? Insights from brown coals of the southeastern Australia Gippsland Basin. Palaeogeogr. Palaeoclimatol. Palaeoecol. 2014, 411, 65-78. [CrossRef]

25. Oikonomopoulos, I.K.; Kaouras, G.; Tougiannidis, N.; Ricken, W.; Gurk, M.; Antoniadis, P. The depositional conditions and the palaeoenvironment of the Achlada xylite-dominated lignite in western Makedonia, Greece. Palaeogeogr. Palaeoclimatol. Palaeoecol. 2015, 440, 777-792. [CrossRef]

26. Korasidis, V.A.; Wallace, M.W.; Dickinson, J.A.; Hoffman, N. Depositional setting for Eocene seat earths and related facies of the Gippsland Basin, Australia. Sediment. Geol. 2019, 390, 100-113. [CrossRef]

27. Oskay, R.G.; Bechtel, A.; Karayiğit, A.İ. Mineralogy, petrography and organic geochemistry of Miocene coal seams in the Kınık coalfield (Soma Basin-Western Turkey): Insights into depositional environment and palaeovegetation. Int. J. Coal Geol. 2019, $210,103205$. [CrossRef]

28. Zieger, L.; Littke, R. Bolsovian (Pennsylvanian) tropical peat depositional environments: The example of the Ruhr Basin, Germany. Int. J. Coal Geol. 2019, 211, 103209. [CrossRef]

29. China Coal Geology Bureau. Sedimentary Environments and Coal Accumulation of Late Permian Coal Formation in Western Guizhou, Southern Sichuan, and Eastern Yunnan, China; Chongqing University Press: Chongqing, China, 1996; p. 216. (In Chinese)

30. Shao, L.; Jones, T.; Gayer, R.; Dai, S.; Li, S.; Jiang, Y.; Zhang, P. Petrology and geochemistry of the high-sulphur coals from the Upper Permian carbonate coal measures in the Heshan Coalfield, southern China. Int. J. Coal Geol. 2003, 55, 1-26. [CrossRef]

31. Dai, S.; Ren, D.; Zhou, Y.; Chou, C.-L.; Wang, X.; Zhao, L.; Zhu, X. Mineralogy and geochemistry of a superhigh-organic-sulfur coal, Yanshan Coalfield, Yunnan, China: Evidence for a volcanic ash component and influence by submarine exhalation. Chem. Geol. 2008, 255, 182-194. [CrossRef]

32. Dai, S.; Zhang, W.; Seredin, V.V.; Ward, C.R.; Hower, J.C.; Song, W.; Wang, X.; Li, X.; Zhao, L.; Kang, H.; et al. Factors controlling geochemical and mineralogical compositions of coals preserved within marine carbonate successions: A case study from the Heshan Coalfield, southern China. Int. J. Coal Geol. 2013, 109-110, 77-100. [CrossRef]

33. Dai, S.; Xie, P.; French, D.; Ward, C.R.; Graham, I.T.; Yan, X.; Guo, W. The occurrence of buddingtonite in super-high-organicsulphur coals from the Yishan Coalfield, Guangxi, southern China. Int. J. Coal Geol. 2018, 195, 347-361. [CrossRef]

34. Dai, S.; Ren, D.; Tang, Y.; Yue, M.; Hao, L. Concentration and distribution of elements in Late Permian coals from western Guizhou Province, China. Int. J. Coal Geol. 2005, 61, 119-137. [CrossRef]

35. Dai, S.; Chou, C.-L.; Yue, M.; Luo, K.; Ren, D. Mineralogy and geochemistry of a Late Permian coal in the Dafang Coalfield, Guizhou, China: Influence from siliceous and iron-rich calcic hydrothermal fluids. Int. J. Coal Geol. 2005, 61, 241-258. [CrossRef]

36. Dai, S.; Wang, X.; Zhou, Y.; Hower, J.C.; Li, D.; Chen, W.; Zhu, X.; Zou, J. Chemical and mineralogical compositions of silicic, mafic, and alkali tonsteins in the late Permian coals from the Songzao Coalfield, Chongqing, Southwest China. Chem. Geol. 2011, 282, 29-44. [CrossRef]

37. Zhao, L.; Ward, C.R.; French, D.; Graham, I.T. Mineralogical composition of Late Permian coal seams in the Songzao Coalfield, southwestern China. Int. J. Coal Geol. 2013, 116-117, 208-226. [CrossRef]

38. Zhuang, X.; Su, S.; Xiao, M.; Li, J.; Alastuey, A.; Querol, X. Mineralogy and geochemistry of the Late Permian coals in the Huayingshan coal-bearing area, Sichuan Province, China. Int. J. Coal Geol. 2012, 94, 271-282. [CrossRef]

39. Dai, S.; Liu, J.; Ward, C.R.; Hower, J.C.; French, D.; Jia, S.; Hood, M.M.; Garrison, T.M. Mineralogical and geochemical compositions of Late Permian coals and host rocks from the Guxu Coalfield, Sichuan Province, China, with emphasis on enrichment of rare metals. Int. J. Coal Geol. 2016, 166, 71-95. [CrossRef] 
40. Svensen, H.; Planke, S.; Polozov, A.G.; Schmidbauer, N.; Corfu, F.; Podladchikov, Y.Y.; Jamtveit, B. Siberian gas venting and the end-Permian environmental crisis. Earth Planet. Sci. Lett. 2009, 277, 490-500. [CrossRef]

41. Cui, Y.; Kump, L.R.; Ridgwell, A. Initial assessment of the carbon emission rate and climatic consequences during the end-Permian mass extinction. Palaeogeogr. Palaeoclimatol. Palaeoecol. 2013, 389, 128-136.

42. He, B.; Zhong, Y.-T.; Xu, Y.-G.; Li, X.-H. Triggers of Permo-Triassic boundary mass extinction in South China: The Siberian Traps or Paleo-Tethys ignimbrite flare-up? Lithos 2014, 204, 258-267. [CrossRef]

43. Vajda, V.; McLoughlin, S.; Mays, C.; Frank, T.D.; Fielding, C.R.; Tevyaw, A.; Lehsten, V.; Bocking, M.; Nicoll, R.S. End-Permian (252 Mya) deforestation, wildfires and flooding-An ancient biotic crisis with lessons for the present. Earth Planet. Sci. Lett. 2020, 529, 115875. [CrossRef]

44. Foster, C.B.; Logan, G.A.; Summons, R.E. The Permian-Triassic boundary in Australia: Where is it and how is it expressed? Proc. R. Soc. Vic. 1998, 110, 247-266.

45. Fielding, C.R.; Frank, T.D.; McLoughlin, S.; Vajda, V.; Mays, C.; Tevyaw, A.P.; Winguth, A.; Winguth, C.; Nicoll, R.S.; Bocking, M.; et al. Age and pattern of the southern high-latitude continental end-Permian extinction constrained by multiproxy analysis. Nat. Commun. 2019, 10, 385. [CrossRef]

46. Shen, S.-Z.; Crowley, J.L.; Wang, Y.; Bowring, S.A.; Erwin, D.H.; Sadler, P.M.; Cao, C.-Q.; Rothman, D.H.; Henderson, C.M.; Ramezani, J.; et al. Calibrating the End-Permian Mass Extinction. Science 2011, 334, 1367-1372. [CrossRef] [PubMed]

47. Tian, B.; Zhang, L. Fossil Atlas of Wangjiazhai Coal Mining District, Shuicheng, Guizhou Province; China Coal Industry Publishing House: Beijing, China, 1980; pp. 2-4. (In Chinese)

48. Yue, W.; Jin, Y.; Wang, Y.; Jin, Y.G. Permian palaeogeographic evolution of the Jiangnan Basin, South China. Palaeogeogr. Palaeoclimatol. Palaeoecol. 2000, 160, 35-44. [CrossRef]

49. Zhang, H.; Cao, C.-q.; Liu, X.-1.; Mu, L.; Zheng, Q.-f.; Liu, F.; Xiang, L.; Liu, L.-j.; Shen, S.-z. The terrestrial end-Permian mass extinction in South China. Palaeogeogr. Palaeoclimatol. Palaeoecol. 2016, 448, 108-124. [CrossRef]

50. Dai, S.; Chekryzhov, I.Y.; Seredin, V.V.; Nechaev, V.P.; Graham, I.T.; Hower, J.C.; Ward, C.R.; Ren, D.; Wang, X. Metalliferous coal deposits in East Asia (Primorye of Russia and South China): A review of geodynamic controls and styles of mineralization. Gondwana Res. 2016, 29, 60-82. [CrossRef]

51. Zhou, Y.; Bohor, B.F.; Ren, Y. Trace element geochemistry of altered volcanic ash layers (tonsteins) in Late Permian coal-bearing formations of eastern Yunnan and western Guizhou Provinces, China. Int. J. Coal Geol. 2000, 44, 305-324. [CrossRef]

52. Domeier, M.; Torsvik, T.H. Plate tectonics in the late Paleozoic. Geosci. Front. 2014, 5, 303-350. [CrossRef]

53. Feng, M.-S.; Meng, W.-B.; Zhang, C.-G.; Qing, H.-R.; Chi, G.-X.; Wang, J.; Peng, Y.-W.; Wen, H.-G.; Huang, H. Geochronology and geochemistry of the 'green-bean rock' (GBR, a potassium-rich felsic tuff) in the western margin of the Yangtze platform, SW China: Significance for the Olenekian-Anisian boundary and the Paleo-Tethys tectonics. Lithos 2021, 382-383, 105922. [CrossRef]

54. Chou, C.-L. Sulfur in coals: A review of geochemistry and origins. Int. J. Coal Geol. 2012, 100, 1-13. [CrossRef]

55. Scott, A. The Pre-Quaternary history of fire. Palaeogeogr. Palaeoclimatol. Palaeoecol. 2000, 164, 281-329. [CrossRef]

56. Vasilyev, N.V. The Tunguska Meteorite problem today. Planet. Space Sci. 1998, 46, 129-150. [CrossRef]

57. Berner, R.A.; Beerling, D.J.; Dudley, R.; Robinson, J.M.; Wildman, R.A. Phanerozoicatmosphericoxygen. Annu. Rev. Earth Planet. Sci. 2003, 31, 105-134. [CrossRef]

58. Glasspool, I.J.; Scott, A.C. Phanerozoic concentrations of atmospheric oxygen reconstructed from sedimentary charcoal. Nat. Geosci. 2010, 3, 627-630. [CrossRef]

59. Friis, E.M.; Skarby, A. Structurally preserved angiosperm flowers from the Upper Cretaceous of southern Sweden. Nature 1981, 291, 484-486. [CrossRef]

60. Friis, E.M.; Crane, P.R.; Pedersen, K.R. Floral evidence for Cretaceous chloranthoid angiosperms. Nature 1986, 320, 163-164. [CrossRef]

61. Murthy, S.; Mendhe, V.A.; Kavali, P.S.; Singh, V.P. Evidence of recurrent wildfire from the Permian coal deposits of India: Petrographic, scanning electron microscopic and palynological analyses of fossil charcoal. Palaeoworld 2020, 29, 715-728. [CrossRef]

62. Bustin, R.M.; Guo, Y. Abrupt changes (jumps) in reflectance values and chemical compositions of artificial charcoals and inertinite in coals. Int. J. Coal Geol. 1999, 38, 237-260. [CrossRef]

63. Edwards, D.; Axe, L. Anatomical Evidence in the Detection of the Earliest Wildfires. Palaios 2004, 19, 113-128. [CrossRef]

64. van Der Flier-Keller, E.; Fyfe, W.S. Relationships between inorganic constituents and organic matter in a northern Ontario lignite. Fuel 1988, 67, 1048-1052. [CrossRef]

65. Dai, S.; Li, T.; Seredin, V.V.; Ward, C.R.; Hower, J.C.; Zhou, Y.; Zhang, M.; Song, X.; Song, W.; Zhao, C. Origin of minerals and elements in the Late Permian coals, tonsteins, and host rocks of the Xinde Mine, Xuanwei, eastern Yunnan, China. Int. J. Coal Geol. 2014, 121, 53-78. [CrossRef]

66. Burger, K.; Zhou, Y.; Ren, Y. Petrography and geochemistry of tonsteins from the 4th Member of the Upper Triassic Xujiahe formation in southern Sichuan Province, China. Int. J. Coal Geol. 2002, 49, 1-17. [CrossRef]

67. Spears, D.A. The origin of tonsteins, an overview, and links with seatearths, fireclays and fragmental clay rocks. Int. J. Coal Geol. 2012, 94, 22-31. [CrossRef]

68. Susilawati, R.; Ward, C.R. Metamorphism of mineral matter in coal from the Bukit Asam deposit, south Sumatra, Indonesia. Int. J. Coal Geol. 2006, 68, 171-195. 
69. Zhou, Y. The synsedimentary alkalinity-volcanic ash derived tonsteins of Early Longtan age in south-western China. Coal Geol. Explor. 1999, 27, 5-9. (In Chinese with English abstract)

70. Zhou, Y.P.; Ren, Y.L.; Bohor, B.F. Origin and distribution of tonsteins in late permian coal seams of Southwestern China. Int. J. Coal Geol. 1982, 2, 49-77. [CrossRef]

71. Zielinski, R.A. Element mobility during alteration of silicic ash to kaolinite-A study of tonstein. Sedimentology 1985, 32, 567-579.

72. Spears, D.A.; Kanaris-Sotiriou, R. A geochemical and mineralogical investigation of some British and other European tonsteins. Sedimentology 2010, 26, 407-425. [CrossRef]

73. Zhao, L.; Ward, C.R.; French, D.; Graham, I.T. Mineralogy of the volcanic-influenced Great Northern coal seam in the Sydney Basin, Australia. Int. J. Coal Geol. 2012, 94, 94-110. [CrossRef]

74. Kokowska-Pawłowska, M.; Nowak, J. Phosphorus minerals in tonstein; coal seam 405 at Sośnica-Makoszowy coal mine, Upper Silesia, southern Poland. Acta Geol. Pol. 2013, 63, 271-281. [CrossRef]

75. Wang, J.; Shao, L.; Wang, H.; Spiro, B.; Large, D. SHRIMP zircon U-Pb ages from coal beds across the Permian-Triassic boundary, eastern Yunnan, southwestern China. J. Palaeogeogr. 2018, 7, 117-129. [CrossRef]

76. Li, X.; Dai, S.; Nechaev, V.P.; Graham, I.T.; Zhao, J. Mineral Matter in the Late Permian C1 Coal from Yunnan Province, China, with Emphasis on Its Origins and Modes of Occurrence. Minerals 2020, 11, 19. [CrossRef]

77. Isozaki, Y.; Yao, J.; Matsuda, T.; Sakai, H.; Takano, M. Stratigraphy of the Middle-Upper Permian and lowermost Triassic at Chaotian, Sichuan, China: Record of Late Permian double mass extinction event. Proc. Jpn. Acad. 2004, 80, 10-16. [CrossRef]

78. Liao, Z.; Hu, W.; Cao, J.; Wang, X.; Yao, S.; Wu, H.; Wan, Y. Heterogeneous volcanism across the Permian-Triassic Boundary in South China and implications for the Latest Permian Mass Extinction: New evidence from volcanic ash layers in the Lower Yangtze Region. J. Asian Earth Sci. 2016, 127, 197-210. [CrossRef]

79. Bohor, B.F.; Triplehorn, D.M. Tonsteins: Altered Volcanic-Ash Layers in Coal-Bearing Sequences. Geol. Soc. Am. Special Paper 1993, $285,1-44$.

80. Diehl, S.F.; Goldhaber, M.B.; Koenig, A.E.; Lowers, H.A.; Ruppert, L.F. Distribution of arsenic, selenium, and other trace elements in high pyrite Appalachian coals: Evidence for multiple episodes of pyrite formation. Int. J. Coal Geol. 2012, 94, 238-249. [CrossRef]

81. Kolker, A. Minor element distribution in iron disulfides in coal: A geochemical review. Int. J. Coal Geol. 2012, 94, 32-43. [CrossRef]

82. Hower, J.C.; Ruppert, L.F.; Eble, C.F. Lateral variation in geochemistry, petrology, and palynology in the Elswick coal bed, Pike County, Kentucky. Int. J. Coal Geol. 2007, 69, 165-178. [CrossRef]

83. Ruppert, L.F.; Hower, J.C.; Eble, C.F. Arsenic-bearing pyrite and marcasite in the Fire Clay coal bed, Middle Pennsylvanian Breathitt Formation, eastern Kentucky. Int. J. Coal Geol. 2005, 63, 27-35. [CrossRef]

84. Zhang, J.; Ren, D.; Zheng, C.; Zeng, R.; Jing, L. Trace element abundances in major minerals of Late Permian coals from southwestern Guizhou province, China. Int. J. Coal Geol. 2003, 53, 55-64.

85. Ren, D.; Zhao, F.; Dai, S.; Zhang, J.; Luo, K. Geochemistry of Trace Elements in Coal; Science Press: Beijing, China, 2006; p. 556. (In Chinese)

86. Dai, S.; Ren, D.; Chou, C.-L.; Finkelman, R.B.; Seredin, V.V.; Zhou, Y. Geochemistry of trace elements in Chinese coals: A review of abundances, genetic types, impacts on human health, and industrial utilization. Int. J. Coal Geol. 2012, 94, 3-21. [CrossRef]

87. Belkin, H.E.; Zheng, B.; Zhou, D.; Finkelman, R.B. Chronic Arsenic Poisoning from Domestic Combustion of Coal in Rural China: A Case Study of the Relationship Between Earth Materials and Human Health. In Environmental Geochemistry; Elsevier: Amsterdam, The Netherlands, 2008; pp. 401-420.

88. Ding, Z.; Zheng, B.; Long, J.; Belkin, H.E.; Finkelman, R.B.; Chen, C.; Zhou, D.; Zhou, Y. Geological and geochemical characteristics of high arsenic coals from endemic arsenosis areas in southwestern Guizhou Province, China. Appl. Geochem. 2001, 16, 1353-1360. [CrossRef]

89. Zhuang, X.; Querol, X.; Alastuey, A.; Plana, F.; Moreno, N.; Andrés, J.M.; Wang, J. Mineralogy and geochemistry of the coals from the Chongqing and Southeast Hubei coal mining districts, South China. Int. J. Coal Geol. 2007, 71, 263-275. [CrossRef]

90. Zhou, Y.; Ren, Y. Distribution of arsenic in coals of Yunnan Province, China, and its controlling factors. Int. J. Coal Geol. 1992, $20,85-98$. [CrossRef]

91. Karayiğit, A.I.; Bircan, C.; Mastalerz, M.; Oskay, R.G.; Querol, X.; Lieberman, N.R.; Türkmen, I. Coal characteristics, elemental composition and modes of occurrence of some elements in the İsaalan coal (Balıkesir, NW Turkey). Int. J. Coal Geol. 2017, 172, 43-59. [CrossRef] 